\title{
GAMBARAN LINGKUNGAN KERJA, KOMUNIKASI KERJA DAN SEMANGAT KERJA PERAWAT RUMAH SAKIT UMUM PARU Dr. H.A. ROTINSULU BANDUNG
}

\author{
Nasrul Kamal \\ Universitas Pendidikan Indonesia \\ nasrulkamal@student.upi.edu \\ Sumiyati \\ Universitas Pendidikan Indonesia \\ sumiyati@upi.edu \\ Ridwan Purnama \\ Universitas Pendidikan Indonesia \\ ridwanpurnama@upi.edu
}

\begin{abstract}
ABSTRAK
Tujuan - Tujuan penelitian ini adalah untuk mengetahui gambaran lingkungan kerja, komunikasi kerja , dan semangat kerja.

Desain/metodologi/pendekatan - Desain penelitian ini adalah cross sectional method. Penelitian ini menggunakan pendekatan deskriptif dengan metode explanatory survey. Unit analisis perawat sebanyak 107 orang. Pengumpulan data dengan menggunakan kuisioner. Teknik analisis yang digunakan adalah teknik deskriptif dengan menggunakan distribusi frekuensi.

Temuan - Berdasarkan hasil penelitian mneggunakan analisis deskriptif, didapatkan hasil bahwa lingkungan kerja berkategori kondusif, komunikasi kerja berkategori baik dan semangat kerja berkategori tinggi.

Orisinalitas/nilai - Perbedaan dalam penelitian ini terletak pada objek penelitian, waktu penelitian, alat ukur, literatur yang digunakan, teori yang digunakan dan hasil penelitian.
\end{abstract}

Kata Kunci: Lingkungan kerja, Komunikasi Kerja, Semangat Kerja

Jenis Artikel: Studi Kasus

\begin{abstract}
Purpose - The purpose of this study is to see the description of work environment, work communication and morale

Design/methodology/approachh - The design of this study was cross sectional method. This research uses descriptive approach with explanatory survey method. The nurses analysis unit is 107 people. Data collection using questionnaire. The analysis technique used is descriptive technique by using frequency distribution

Findings - Based on the results of the research using descriptive analysis, the results obtained that work environment in the conducive category, wprk communication in the good category, and morale in the high category.

Originality/value - The differences in this study located on an object research, time research, a measuring instrument, literature that used, the theory that is used and the results of the study.
\end{abstract}

Keywords: Work Environment, Work Communication, Morale

Article Type : Research Paper 


\section{PENDAHULUAN}

Sumber daya manusia memegang peranan yang sangat penting dalam organisasi, karena sumber daya manusia merencanakan, melaksanakan dan mengendalikan setiap kegiatan organisasi untuk mencapai tujuan., oleh sebab itu sumber daya manusia harus mendapat perhatian yang lebih serius dibandingkan dengan sumber daya lainnya karena memiliki pikiran, perasaan dan perilaku yang dapat mempengaruhi keberhasilan organisasi (Eko Sulistiyono et al, 2016). Dalam menghadapi persaingan yang semakin ketat dewasa ini, sebuah organisasi atau perusahaan dituntut untuk selalu menyesuaikan diri terhadap segala perubahan yang terjadi agar dapat bertahan dalam persaingan. Tujuan organisasi akan dapat tercapai jika sumber daya yang menggerakkan perusahaan tersebut memiliki semangat kerja yang tinggi (Putu Duwita Permaningratna, 2012). Keberadaan manusia sebagai sumber daya manusia adalah sangat penting dalam organisasi karena sumber daya manusia menunjang organisasi melalui karya, bakat, kreativitas, dorongan dan peran nyata seperti yang dapat dilihat dalam setiap organisasi (Masharyono \& Senen, 2015:121). Organisasi membutuhkan sumber daya manusia yang bisa bekerja efisien dan efektif dan organisasi harus mampu mengambil alih pengelolaan karyawan dengan baik (Sumiyati \& Masharyono, 2016). Sumber daya manusia adalah faktor dinamis yang mampu menentukan sebuah organisasi, sehingga instansi dengan sumber daya manusia yang handal akan menang dalam persaingan (Senen \& Triananda, 2016a).

Semangat kerja karyawan adalah kata kunci baru dalam manajemen sumber daya manusia strategis. Karyawan dengan semangat juang yang tinggi akan mengungguli dibandingkan dengan semangat yang rendah (Upadhyay, 2012). Semangat kerja merupakan hal penting yang harus dijalani oleh setiap karyawan di perusahaan manapun karena semangat kerja menggambarkan perasaan senang pada setiap individu atau kelompok serta rasa puas terhadap kebijakan, karir, kondisi kerja, kerja sama, dan lingkungan (Fauji, 2013).

Masalah semangat kerja menjadi perhatian dunia saat ini, penekanan dalam upaya untuk membangun organisasi hampir menuju pada konsep individualisme yang mengarah pada semangat kerja karyawan yang rendah dan pada akhirnya mengarah pada tingkat turnover yang tinggi. Ini juga merupakan masalah yang muncul bagi orang berprestasi tinggi yang sangat termotivasi terhadap pengakuan dan harga diri. Keberhasilan atau kegagalan perusahaan banyak tergantung pada semangat para karyawan, organisasi membutuhkan karyawan dengan semangat yang tinggi untuk membangun semangat dalam pola pikir karyawan (P Raja, 2015). Semangat yang tinggi berarti karyawan puas dengan pekerjaannya, menempatkan upaya kreatif, mengambil inisiatif, berkomitmen berorganisasi dan berfokus pada pencapaian tujuan organisasi (Rewa \& Tiwari, 2014).

Semangat kerja menjadi bahan perhatian para peneliti, seperti yang dilakukan oleh Zia (2016), menyatakan bahwa seiring globalisasi adanya peningkatan masalah semangat kerja karyawan. Selain itu karyawan dengan semangat yang rendah dapat menyebabkan turnover karyawan yang tinggi dan penurunan produktivitas. Semangat kerja di dalam suatu organisasi berarti menunjukkan rasa kegairahan dalam melaksanakan pekerjaan dan mendorong mereka untuk bekerja secara lebih baik dan lebih produktif (Fauji, 2013).

Indonesia dengan skala tantangan sangat besar dan luas, membutuhkan selain semangat kerja, juga sentuhan visioner, cerdas, dan ikhlas," cuit mantan perekonomian Hatta Rajasa. Hatta meyakini, apa yang akan dihadapi Indonesia dalam lima tahun kedepan tidaklah mudah, pasalnya ekonomi global akan kembali mengalami perlambatan dan ini tentu saja akan berdampak kedalam negeri. Berikut terjadinya penurunan pertumbuhan ekonomi dari tren tinggi menjadi moderat, tahun 2012 pertumbuhan Indonesia sekitar 6,5\% namun tahun 2017 diprediksi berkisar 5,3\%. Untuk itu pemerintah harus mengambil langkah kebijakan yang serius agar tidak tergelincir pada pertumbuhan ekonomi rendah, perkembangan perusahaan jasa yang semakin pesat membawa dampak timbulnya persaingan usaha yang semakin ketat dalam bidang pelayanan terhadap pelanggan, kondisi ini menuntut setiap perusahaan yakni rumah sakit untuk memiliki keunggulan-keunggulan kompetitif, respons yang cepat dan tanggap agar dapat bersaing dengan perusahaan yang bergerak dalam bidang sejenis. Keungggulan-keunggulan kompetitif ini dapat diperoleh dengan memiliki sumber daya manusia yang berkualitas dan memiliki semangat kerja yang tinggi terhadap perusahaan sehingga dapat memberdayakan sumber daya yang dimilikinya secara efektif, efisien dan produktif (Sumber: www.metrotvnews.com).

Menteri Kesehatan Nila Farida Moeloek mengemukakan bahwa terjadinya penurunan kinerja perawat Indonesia saat ini, berdampak pada rendahnya pelayanan kesehatan yang diterima masyarakat. Sehingga sebagian rumah sakit di Indonesia mengalami penurunan tingkat kunjungan pasien yang berdampak pada buruknya produktivitas rumah sakit. (Sumber: http://news.liputan6.com). Pernyataan yang sama 
disampaikan oleh Sekretaris Jenderal Kemenkes Untung Suseno Sutarjo, bahwa kinerja perawat memiliki peran yang penting dalam pertumbuhan sektor kesehatan dalam negeri sehingga kinerja perawat perlu ditingkatkan perannya. Kurang optimalnya kinerja perawat akan berdampak menurunnya tingkat kepercayaan masyarakat, sehingga masyarakat lebih memilih memutuhkan untuk pindah ke rumah sakit di luar negeri, serta nama baik rumah sakit menjadi dipertaruhkan di hadapan masyarakat. (Sumber: www.kemenkes.go.id).

Banyak faktor yang mempengaruhi semangat kerja karyawan, maka beberapa faktor yang sama dan terkait satu sama lain dikelompokkan menjadi satu. Dalam penelitian ini diteliti lima variabel yang mempengaruhi semangat kerja karyawan yaitu: (1) penempatan, (2) kompensasi, (3) kesempatan berprestasi, (4) komunikasi dan (5) lingkungan. Kelima faktor tersebut diteliti dengan alasan bahwa dengan penempatan yang tepat, pemberian kompensasi yang adil, pemberian kesempatan berprestasi yang terbuka, hubungan kerja atau komunikasi yang kondusif dan lingkungan yang baik dapat meningkatkan semangat kerja karyawan. Dengan semangat kerja karyawan yang tinggi organisasi akan mampu meningkatkan efektivitas dan efisiensi kerja (Eko Sulistiyono et al, 2016). Menurut Zainun (2013) ada beberapa faktor yang mempengaruhi semangat kerja karyawan yaitu: komunikasi yang baik dan hubungan harmonis antara pimpinan dan bawahan terutama antara pemimpinan yang sehari-hari langsung berhadapan dan berkomunikasi dengan para karyawan yang dibawahinya, kepuasan para karyawan terhadap tugas, pekerjaannya dan mengerjakan tugas dengan tanggung jawab karena atasan yang berkomunikasi secara baik dengan karyawan dalam memberikan tugas, karyawan berada pada lingkungan kerja yang sehat dan baik, seperti lingkungan yang tidak kotor, tidak lembab, dan suhu teratur.

Subechi Maulana, (2015) mengemukakan bahwa dengan adanya lingkungan yang memadai tentunya akan membuat karyawan betah bekerja, sehingga akan timbul semangat kerja dan kegairahan kerja karyawan dalam melaksanakan pekerjaannya, yang berpengaruh pada kinerja karyawan yang meningkat. Sedangkan menurut Noviyanti, Suwena, \& Haris (2015) menyatakan bahwa salah satu faktor yang mempengaruhi semangat kerja yaitu lingkungan kerja, hal ini dikarenakan pegawai akan memiliki semangat yang tinggi ketika berada di lingkungan yang nyaman. Menurut Upadhyay \& Gupta (2012) menyatakan bahwa lingkungan kerja dapat mempengaruhi semangat kerja hal ini dikarenakan bahwa semangat kerja dapat menciptakan lingkungan kerja yang positif dan meningkatkan produktivitas pegawai.

Wantania \& Lapian, (2015) menyatakan bahwa komunikasi dan lingkungan berpengaruh positif terhadap semangat kerja, semakin baiknya komunikasi dan lingkungan akan memberi dorongan yang tinggi untuk semangat karyawan dalam bekerja. Baker \& McCabe (2010) juga menyatakan bahwa komunikasi berpengaruh signifikan terhadap semangat kerja yang artinya bahwa semakin intens komunikasi yang dilakukan maka akan meningkatkan semangat kerja. Sementara menurut (Mulyana, 2014: 68) komunikasi adalah transmisi informasi, gagasan, emosi, keterampilan, dan sebagainya dengan menggunakan simbol-simbol, kata-kata, gambar, figur, grafik, dan sebagainya. Tindakan atau proses transmisi itulah yang biasa disebut komunikasi.

Berdasarkan latar belakang masalah di atas, maka tujuan penelitian ini adalah untuk memperoleh hasil temuan mengenai: (1) gambaran lingkungan kerja, (2) gambaran komunikasi kerja, dan (3) gambaran semangat kerja kerja

\section{KAJIAN PUSTAKA}

Perilaku organisasi secara luas berbicara tentang bagaimana individu berpikir, berinteraksi, dan bertindak dalam struktur sosial formal dan merupakan studi tentang bagaimana organisasi dalam mengembangkan dan memelihara elemen struktur sosial individu yang mempengaruhi perilaku mereka (Secchi \& Neumann, 2016). Berikutnya Robbins \& Judge (2016) mengemukakan bahwa proses pembentukan perilaku tersebut dimulai dari setiap anggota organisasi yang dilakukan secara ilmiah, perilaku organisasi adalah suatu bidang studi yang mempelajari dampak perorangan, kelompok, dan struktur pada perilaku dalam organisasi dengan maksud menerapkan pengetahuan tentang hal-hal tersebut demi perbaikan efektivitas organisasi. Sementara menurut (Senen, Sumiyati, \& Masharyono, 2016) organisasi membutuhkan sumber daya manusia yang bisa bekerja efisien dan efektif dan organisasi harus mampu mengambil alih pengelolaan karyawan dengan baik.

Perilaku organisasi memiliki tiga jenis variabel (masukan, proses, dan keluaran) pada tiga level analisis (individu, kelompok, dan organisasi). Masukan (input) adalah variabel seperti kepribadian, struktur kelompok, dan budaya organisasi yang berujung pada proses. Proses pada level individu mencakup emosi dan suasana hati, motivasi, persepsi, serta pengambilan keputusan. Keluaran (output) pada level individu meliputi sikap dan stres, kinerja 
tugas, perilaku kewargaan, dan perilaku penarikan diri (Robbins \& Judge, 2015).

Bagian proses dibagi menjadi tiga level, yaitu level individu (individual level), level grup (group level), dan level organisasi (organizational level). Level individu terdiri dari emosional dan suasana hati (emotional and moods), motivasi (motivation), persepsi (perception), dan pengambilan keputusan (decision making).

Motivasi adalah kekuatan dalam seseorang yang mempengaruhi arah, intensitas, dan kegigihannya dari perilaku sukarela (McShane \& Glinow, 2018). Robbins \& Judge (2016) menjelaskan motivasi memiliki beberapa elemen pembentuk, salah satu elemen tersebut adalah lingkungan fisik dan sosial. Robbins \& Judge (2016) menjelaskan bahwa lingkungan adalah institusi atau kekuatan di luar yang berpotensi mempengaruhi kinerja organisasi, lingkungan disimpulkan menjadi dua, yaitu lingkungan sosial dan lingkungan yang fisik (Nuryanti \& Rahmawati, 2016).

Sunyoto (2012) menjelaskan lingkungan kerja merupakan segala sesuatu yang ada di sekitar para pekerja dan yang dapat memengaruhi dirinya dalam menjalankan tugastugas yang dibebankan, misalnya kebersihan, musik, penerangan dan lain-lain (Widyanata \& Senen, 2016). Lingkungan kerja merupakan kondisi sekitar atau suasana yang ada disekitar pegawai tersebut, sebagaimana diungkapkan (Gouzali Saydam, 2008: 226) yang berpendapat bahwa lingkungan kerja adalah keseluruhan sarana dan prasarana kerja yang ada disekitar pegawai yang sedang melakukan pekerjaan yang dapat mempengaruhi pelaksanaan pekerjaan itu sendiri. Sedamaryanti (2011) menyatakan bahwa lingkungan kerja adalah keseluruhan alat perkakas, lingkungan di mana seseorang bekerja, metode kerja, serta pengaturan kerja. Nuryanti \& Rahmawati (2016) lingkungan adalah bagian dari lingkungan yang berhubungan langsung untuk pencapaian tujuan sebuah organisasi.

$$
\text { Menurut Sedarmayanti }
$$
menyatakan bahwa secara garis besar, jenis lingkungan kerja terbagi menjadi dua faktor yaitu faktor lingkungan kerja fisik dan faktor lingkungan kerja non fisik. Lingkungan kerja fisik adalah lingkungan yang berada disekitar pekerja itu sndiri. Kondisi di lingkungan kerja dapat mempengaruhi kepuasan kerja karyawan yang meliputi. Lingkungan kerja non fisik/sosial adalah hal-hal yang menyangkut dengan hubungan sosial dan keorganisasian.

Untuk menciptakan lingkungan kerja yang baik ada beberapa hal yang harus diperhatikan yaitu, bangunan tempat kerja, ruang kerja yang lega, ventilasi pertukaran udara, tersedianya tempat-tempat ibadah keagamaan, tersedianya sarana angkutan khusus maupun umum untuk karyawan nyaman dan mudah (Siagian, 2006: 63).

Robbins \& Judge (2016) membuat sebuah model perilaku organisasi yang isinya membagi perilaku organisasi menjadi 3 tahapan, 1) masukan, 2) proses, dan 3) hasil. Tahapan masukan meliputi level individu, level kelompok, dan level organisasi. Level kelompok terdiri atas, 1) dasar dari perilaku kelompok, 2) memahami kerja tim, 3) komunikasi, 4) kepemimpinan, 5) kekuasaan dan politik, 6) konflik dan negosiasi, dan 7) dasar pada struktur organisasi. Komunikasi kerja masuk ke dalam bagian komunikasi. Menurut Senen \& Triananda (2016) komunikasi merupakan kekuatan utama dalam pembentukan organisasi, komunikasi dinamis membuat sistem kerjasama dalam organisasi dan menghubungkan tujuan organisasi serta komunikasi yang baik juga bisa meningkatkan kinerja karyawan dengan tepat.

Komunikasi merupakan proses penyampaian atau penerimaan pesan dari satu orang kepada orang lain, baik langsung maupun tidak langsung, secara tertulis, secara lisan maupun bahasa non verbal (Usman, 2011: 420). Sementara menurut Mulyana (2014: 68) komunikasi merupakan transmisi informasi, gagasan, emosi, keterampilan, dan sebagainya dengan menggunakan simbol-simbol, kata-kata, gambar, figur, grafik, dan sebagainya. Tindakan atau proses transmisi itulah yang biasa disebut komunikasi.

A Devito (2011: 24) menyatakan bahwa komunikasi mengacu pada tindakan, oleh satu orang atau lebih, yang mengirim dan menerima pesan yang terdistorsi oleh gangguan (noise), terjadi dalam suatu konteks tertentu, mempunyai pengaruh tertentu, dan ada kesempatan untuk melakukan umpan balik. Menurut Mangkunegara, (2014: 54) mengemukakan komunikasi adalah pemindahan informasi dan pemahaman dari seseorang kepada orang lain atau kontak antar seseorang kepada orang lain, sehingga terjadi transfer infomasi.

Menurut Robbins \& Judge (2016) komunikasi kerja dibentuk atas 3 dimensi, yaitu downward communication adalah komunikasi yang mengalir dari satu tingkat kelompok atau organisasi ke tingkat yang lebih rendah. Kelompok pemimpin dan manajer menggunakannya untuk menetapkan tujuan, memberikan instruksi kerja, menjelaskan kebijakan dan prosedur, titik masalah-masalah yang perlu diperhatikan, dan umpan balik tawaran tentang kinerja. Upward communication mengalir ke tingkat yang lebih tinggi dalam kelompok atau organisasi. Komunikasi ini digunakan untuk memberikan umpan balik kepada petinggi, 
menginformasikan mereka tentang kemajuan menuju tujuan, dan menyampaikan masalah. Komunikasi ke atas membuat manajer menyadari bagaimana perasaan pegawai pekerjaan mereka, rekan kerja, dan organisasi pada umumnya. Manajer juga mengandalkan komunikasi ke atas untuk ide-ide tentang bagaimana kondisi dapat ditingkatkan. Lateral communication adalah komunikasi yang terjadi antara anggota kelompok kerja yang sama, anggota kelompok kerja pada tingkat yang sama, manajer pada tingkat yang sama, atau pekerja horizontal setara lainnya.

Robbins \& Judge (2016) berpendapat bahwa hambatan komunikasi dibagi menjadi 8 kategori, yaitu penyaringan (filtering), seleksi persepsi (selective perception), informasi yang berlebihan (information overload), emosi (emotion), bahasa (language), keheningan (silence), penangkapan komunikasi (communication apprehension, kebohongan (lying).

Perilaku setiap karyawan sangat berbeda antara satu sama lain, begitu pun terlihat dalam organisasi. Perilaku itu sendiri adalah suatu fungsi dari interaksi antara seorang individu dengan lingkungannya. Dilihat dari sifatnya, perbedaan perilaku karyawan itu disebabkan karena kemampuan, kebutuhan, cara berpikir untuk menentukan pilihan perilaku, pengalaman dan reaksi yang ditimbulkan (Schermerhorn, Hunt, Osborn, \& Uhl-Bien, 2010: 4).

Teori motivasi yang terbaik adalah teori hierarki kebutuhan. Teori hierarki kebutuhan tersebut menjelaskan lima kebutuhan manusia, yaitu : 1) fisiologis, 2) rasa aman, 3) sosial, 4) penghargaan, dan 5) aktualisasi diri (Robbins \& Judge, 2016). Semangat kerja muncul dari faktor penghargaan pada karyawan, karena dengan memberikan penghargaan kepada karyawan akan meningkatkan semangat kerja (M. Manullang, 2000).

Karyawan dengan semangat juang yang tinggi akan mengungguli dibandingkan dengan semangat yang rendah (Upadhyay, 2012). Semangat kerja merupakan hal penting yang harus dijalani oleh setiap karyawan di perusahaan manapun karena semangat kerja menggambarkan perasaan senang pada setiap individu atau kelompok serta rasa puas terhadap kebijakan, karir, kondisi kerja, kerja sama, dan lingkungan kerja (Fauzi, 2013).

Semangat kerja adalah kegiatan dalam melakukan pekerjaan secara lebih giat, sehingga dengan demikian pekerjaan akan diharapkan lebih cepat dan lebih baik (S.Nitisemito, 2014: 160). Semangat kerja merupakan hal penting yang harus dijalani oleh setiap karyawan di perusahaan manapun karena semangat kerja menggambarkan perasaan senang pada setiap individu atau kelompok serta rasa puas terhadap kebijakan, karir, kondisi kerja, kerja sama, dan lingkungan kerja (Fauzi, 2013).

Beberapa indikator semangat kerja yang dikemukakan oleh S.Nitisemito (2014: 427), diantaranya adalah sebagai berikut, naiknya produktivitas karyawan, karyawan yang semangat kerjanya tinggi cenderung melaksanakan tugastugas sesuai waktu tidak menunda pekerjaan dengan sengaja serta mempercepat pekerjaan dan sebagainya; tingkat absensi rendah, tingkat absensi rendah merupakan salah satu indikasi meningkatnya semangat kerja, karena persentase absen seluruh karyawan rendah; labour turnover, karyawan yang menurun merupakan salah satu indikasi meningkatnya semangat kerja, hal ini dapat disebabkan oleh kesenangan mereka bekerja pada perusahaan tersebut; dan berkurangnya kegelisahaan, semangat kerja karyawan akan meningkat apabila mereka tidak gelisah. Kegelisahan dapat dilihat melalui bentuk keluhan, ketidaktenagaan bekerja, dan hal-hal lainnya.

Menurut S.Nitisemito (2014), faktor-faktor yang mempengaruhi semangat kerja seperti, gaji yang cukup, memperhatikan kebutuhan rohani, perlu menciptakan suasana santai, tempatkan karyawan pada posisi yang tepat, perasaaan aman dan masa depan, fasilitas yang memadai.

Berdasarkan penjelasan mengenai pengaruh lingkungan kerja dan komunikasi kerja terhadap semangat kerja, maka disusun sebuah paradigma pengaruh lingkungan kerja dan komunikasi kerja terhadap semangat kerja secara jelas digambarkan dalam Gambar 1 sebagai berikut:

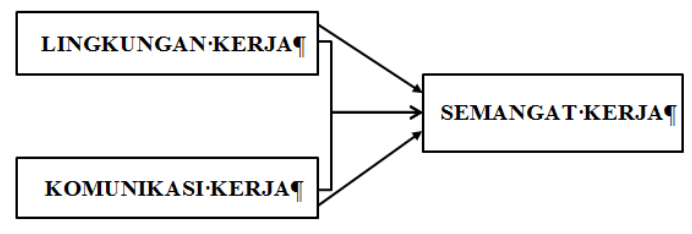

\section{GAMBAR 1 PARADIGMA PENELITIAN}

\section{METODE PENELITIAN}

Penelitian ini dilakukan untuk mengetahui pengaruh lingkungan kerja dan komunikasi kerja terhadap semangat kerja perawat Rumah Sakit Paru Dr. H.A. Rotinsulu Bandung. Adapun yang menjadi objek penelitian sebagai variabel $X$ atau variabel bebas (independent variabel) adalah lingkungan kerja dengan dimensinya yang mencakup lingkungan kerja fisik dan lingkungan kerja non-fisik/sosial. Serta komunikasi kerja dengan dimensinya yang mencakup downward communication, upward communication, dan lateral communication.

Masalah penelitian yang merupakan variabel (Y) atau variabel terikat (dependent variabel) adalah semangat kerja dengan dimensinya yang 
mencakup naiknya produktivitas karyawan, tingkat absensi rendah, labor turnover, dan berkurangnya kegelisihan.

Penelitian ini dilakukan di Rumah Sakit Paru Dr. H.A. Rotinsulu Bandung yang berlokasi di Jalan Bukit Jarian No.40, Kelurahan Ciumbuleuit, Kecamatan Cidadap, Kota Bandung, Jawa Barat. Adapun yang menjadi objek penelitian ini adalah tanggapan responden tentang lingkungan kerja dan komunikasi kerja terhadap semangat kerja. Sedangkan yang menjadi unit analisis adalah perawat Rumah Sakit Paru Dr. H.A. Rotinsulu Bandung. Penelitian ini dilakukan dalam kurun waktu kurang dari satu tahun, maka pendekatan yang digunakan adalah metode cross sectional method, dimana penelitian ini dengan cara mempelajari objek dalam kurun waktu tertentu atau tidak berkesinambungan dalam jangka waktu panjang.

Berdasarkan tingkat penjelasan dan bidang penelitian, maka jenis penelitian ini adalah penelitian deskriptif, dengan metode penelitian yang digunakan adalah explonatory survey. Populasi dalam penelitian ini adalah perawat Rumah Sakit Umum Avisena yang berjumlah 370 orang.

Teknik penarikan sampel yang digunakan dalam penelitian ini adalah dengan menggunakan rumus Tabachnick dan Fidell. Rumus yang digunakan untuk mengukur sampel adalah sebagai berikut (Tabachnick \& Fidell, 2013)

$$
\begin{gathered}
N \geq 50+8 \mathrm{~m} \\
\quad \text { atau } \\
N \geq 104+\mathrm{m}
\end{gathered}
$$

Keterangan:

$$
\mathrm{m}=\text { jumlah variabel }
$$$$
\mathrm{N} \quad=\text { jumlah sampel }
$$

Perhitungan jumlah sampel yang digunakan dalam penelitian ini adalah sebagai berikut:

$$
\begin{gathered}
N \geq 104+\mathrm{m} \\
\boldsymbol{N} \geq 104+3 \\
\boldsymbol{N} \geq 104+3 \\
\boldsymbol{N} \geq 107
\end{gathered}
$$

Jadi, dalam penelitian ini ukuran sampel minimal dalam penelitian ini adalah 107 responden.

Secara statistik, hipotesis yang akan diuji dalam rangka pengambilan keputusan penerimaan atau penolakan hipotesis dapat dirumuskan sebagai berikut:

\section{Hipotesis 1}

$\mathrm{H}_{0}: \rho=0$, artinya gambaran lingkungan kerja diprediksi tidak kondusif.

Ha $: \rho>0$, artinya gambaran lingkungan kerja diprediksi kondusif.

2. Hipotesis 2

$\mathrm{H}_{0}: \rho=0$, artinya gambaran komunikasi kerja diprediksi buruk.
Ha : $\rho>0$, artinya artinya gambaran komunikasi kerja diprediksi baik.

3. $\mathrm{H}_{0}: \rho=0$, artinya gambaran semangat kerja diprediksi rendah.

Ha $: \rho>0$, artinya gambaran semangat kerja diprediksi tinggi.

\section{HASIL PENELITIAN DAN PEMBAHASAN}

Lingkungan kerja pada dasarnya berkatian dengan elemen-elemen atau berbagai macam faktor yang ada di sekitar pegawai, yang berpengaruh baik secara langung maupun tidak langsung terhadap performa pegawai perusahaan. Oleh karena itu, menjadi sebuah keharusan bagi manajemen perusahaan untuk memperhatikan secara serius komponen lingkungan kerja agar tercipta lingkungan kerja yang kondusif. Wibowo, Musadieq, \& Nurtjahjono (2014) lingkungan kerja sebagai kehidupan sosial, psikologi, dan fisik dalam perusahaan yang berpengaruh terhadap pekerja dalam melaksanakan tugasnya. Menurut Sarode \& Shirsath (2016) lingkungan kerja menjadi keseluruhan alat perkakas dan bahan yang dihadapi sekitarnya di mana seseorang bekerja dengan metode kerjanya, serta pengaturan kerjanya baik untuk perseorangan maupun sebagai kelompok.

Lingkungan kerja dalam menjalankan tujuannya tidak terlepas dari ke dua dimensi yang membentuknya, 1) lingkungan kerja fisik dan 2) lingkungan kerja sosial (psikis) yang membentuknya (Arbeidlivets, 2016). Menurut Marihot (2009) lingkungan fisik merupakan hal atau sesuatu yang berada di sekitar para pekerja yang dirasakan secara fisik melalui indera dan dapat memengaruhi diri pekerja dalam menjalankan tugas-tugas yang dibebankan. Sedangkan lingkungan kerja psikis (non fisik) merupakan hal atau sesuatu yang ada disekitar pekerja yang hanya dapat dirasakan secara psikologis tidak dengan indera dan dapat memengaruhi diri pekerja dalam menjalankan tugas-tugas yang dibebankan.

Berdasarkan hasil pengolahan data yang dilakukan melalui penyebaran angket pada perawat RS Paru Dr. H.A. Rotinsulu Bandung, lingkungan kerja dapat diukur melalui perhitungan rata-rata dimensi dan perhitungan skor keseluruhan. Berikut ini dipaparkan hasil dari rekapitulasi perhitungan skor:

TABEL 1

\section{REKAPITULASI DIMENSI} LINGKUNGAN KERJA

\begin{tabular}{llccc}
\hline No & Dimensi & Skor Ideal & Total Skor & $\%$ \\
\hline 1 & Lingkungan kerja fisik & 11.984 & 9.854 & 82,23 \\
2 & Lingkungankerja non-fisk & 5.992 & 4.969 & 82,93 \\
& TOTAL & $\mathbf{1 7 . 9 7 6}$ & $\mathbf{1 4 . 8 2 3}$ & $\mathbf{8 2 , 4 6}$ \\
\hline
\end{tabular}

Berdasarkan Tabel 1 rekapitulasi dimensi lingkungan kerja skor tertinggi terdapat pada 
dimensi lingkungan kerja non-fisik dengan peroleh skor 4.969, termasuk kedalam kategori kondusif $(82,23 \%)$. Dalam hal ini menunjukan lingkungan kerja non-fisik memiliki kondisi yang baik. Menurut Mangkunegara (2014:105) mengungkapkan bahwa lingkungan kerja nonfisik/sosial adalah semua aspek fisik psikologis kerja dan peraturan kerja yang dapat mempengaruhi kepuasan kerja dan pencapaian produktivitas.

Sementara skor terendah terdapat pada dimensi lingkungan kerja fisik diperoleh skor 9.854, termasuk kedalam kategori kondusif $(82,23 \%)$. Menurut Wilkinson et al. (2017) bahwa kenyamanan dan keamanan harus diperhatikan agar karyawan tetap berada dalam perusahaan, jika lingkungan kerja tidak terpenuhi sesuai dengan kebutuhan maka karyawan akan meninggalkan perusahaan. Karyawan yang memiliki kinerja tidak baik dapat dinilai dari lingkungan kerjanya yang mendukung atau tidak (Robbins \& Judge, 2015). Kualitas dan kuantitas kerja dihasilkan oleh karyawan yang dipengaruhi oleh lingkungan kantor, dan kondisi lingkungan yang buruk dapat menyebabkan produktivitas pegawai tidak efisien serta mengurangi kepuasan kerja mereka, yang pada gilirannya akan berdampak pada kesejahteraan finansial dari organisasi (Sarode \& Shirsath, 2016).

Secara keseluruhan variabel lingkungan kerja memperoleh skor 14.823, apabila di persentasekan kedalam skor ideal maka diperoleh persentase sebesar $82,46 \%$, dengan demikian variabel lingkungan kerja berada pada kategori kondusif. Sedangkan dilihat dari garis kontinum yang telah dihitung adalah:

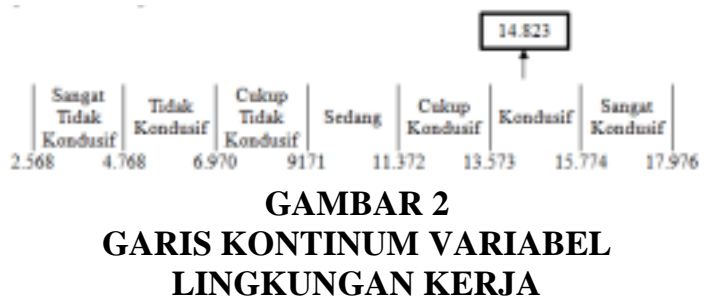

Berdasarkan Gambar 2 pada nilai kontinum variabel lingkungan kerja yaitu 14.823 sesuai dengan data penelitian yaitu termasuk kedalam kategori kondusif, dengan demikian dapat dikatakan bahwa lingkungan kerja di RS Paru Dr. H.A. Rotinsulu Bandung dirasakan oleh perawat kondusif.

Berdasarkan hasil penelitian dari angket yang disebar kepada 107 responden diketahui bahwa lingkungan kerja RS Paru Dr. H.A. Rotinsulu Bandung mencapai skor 14.823 dari skor kriterium atau jumlah maksimal perolehan nilai responden terletak pada daerah 13.573 15.774, sehingga dapat dikatakan bahwa lingkungan kerja yang dimiliki oleh RS Paru Dr.
H.A. Rotinsulu Bandung telah diaplikasikan dengan cukup baik, namun lingkungan kerja tersebut perlu ditingkatkan lagi karena semua dimensi berada di bawah skor ideal. Kualitas dan kuantitas kerja dihasilkan oleh karyawan yang dipengaruhi oleh lingkungan kantor, dan kondisi lingkungan yang buruk dapat menyebabkan produktivitas pegawai tidak efisien serta mengurangi kepuasan kerja mereka, yang pada gilirannya akan berdampak pada kesejahteraan finansial dari organisasi (Sarode \& Shirsath, 2016)

Senen \& Triananda (2016) mengemukakan komunikasi merupakan kekuatan utama dalam pembentukan organisasi, komunikasi dinamis membuat sistem kerjasama dalam organisasi dan menghubungkan tujuan organisasi serta komunikasi yang baik juga bisa meningkatkan kinerja karyawan dengan tepat. Menurut (Mangkunegara, 2014: 54) komunikasi adalah pemindahan informasi dan pemahaman dari seseorang kepada orang lain atau kontak antar seseorang kepada orang lain, sehingga terjadi transfer infomasi. Dimensi komunikasi kerja dibagi menjadi 3 yaitu, downward communication, upward communication, dan lateral communication (Robbins \& Judge, 2016).

Downward communication komunikasi yang mengalir dari satu tingkat kelompok atau organisasi ke tingkat yang lebih rendah. Kelompok pemimpin dan manajer menggunakannya untuk menetapkan tujuan, memberikan instruksi kerja, menjelaskan kebijakan dan prosedur, titik masalah-masalah yang perlu diperhatikan, dan umpan balik tawaran tentang kinerja (Robbins \& Judge, 2016).

Upward communication mengalir ke tingkat yang lebih tinggi dalam kelompok atau organisasi. Komunikasi ini digunakan untuk memberikan umpan balik kepada petinggi, menginformasikan mereka tentang kemajuan menuju tujuan, dan menyampaikan masalah. Komunikasi ke atas membuat manajer menyadari bagaimana perasaan pegawai pekerjaan mereka, rekan kerja, dan organisasi pada umumnya. Manajer juga mengandalkan komunikasi ke atas untuk ide-ide tentang bagaimana kondisi dapat ditingkatkan (Robbins \& Judge, 2016).

Lateral communication adalah komunikasi yang terjadi antara anggota kelompok kerja yang sama, anggota kelompok kerja pada tingkat yang sama, manajer pada tingkat yang sama, atau pekerja horizontal setara lainnya (Robbins \& Judge, 2016).

Berdasarkan hasil pengolahan data yang dilakukan melalui penyebaran angket pada perawat RS Paru Dr. H.A. Rotinsulu Bandung, komunikasi kerja dapat diukur melalui perhitungan rata-rata dimensi dan perhitungan 
skor keseluruhan. Berikut ini dipaparkan hasil dari rekapitulasi perhitungan skor:

TABEL 2

\section{REKAPITULASI DIMENSI} KOMUNIKASI KERJA

\begin{tabular}{ccccc}
\hline No & Dimensi & Skor Ideal & Total Skor & \% \\
\hline 1 & Downward Communication & 2.247 & 1.927 & 85,76 \\
2 & Upward Communication & 2.247 & 1.936 & 86,16 \\
3 & Lateral Communication & 2.247 & 1.914 & 85,18 \\
& TOTAL & $\mathbf{6 . 7 4 1}$ & $\mathbf{5 . 7 7 7}$ & $\mathbf{8 5 , 6 9}$ \\
\hline
\end{tabular}

Berdasarkan Tabel 2 rekapitulasi dimensi komunikasi kerja, skor tertinggi terdapat pada dimensi upward communication dengan peroleh skor 1.936, termasuk dalam kategori baik $(86,16 \%)$. Dalam hal ini menunjukan keterampilan yang dimiliki oleh perawat RS Paru Dr. H.A. Rotinsulu Bandung dapat dikatakan baik. Upward communication mengalir ke tingkat yang lebih tinggi dalam kelompok atau organisasi (Robbins \& Judge, 2016).

Sementara skor terendah terdapat pada dimensi lateral communication dengan perolehan skor 1.914 , termasuk kategori baik $(85,18 \%)$. Dalam hal ini kurangnya lateral communication yang lakukan oleh perawat RS Paru Dr. H.A. Rotinsulu Bandung. Lateral communication adalah komunikasi yang terjadi antara anggota kelompok kerja yang sama, anggota kelompok kerja pada tingkat yang sama, manajer pada tingkat yang sama, atau pekerja horizontal setara lainnya (Robbins \& Judge, 2016).

Secara keseluruhan variabel komunikasi kerja memperoleh skor 5.777, apabila di persentasekan kedalam skor ideal maka diperoleh persentase sebesar $85,69 \%$, dengan demikian variabel komunikasi kerja berada pada kategori baik. Sedangkan dilihat dari garis kontinum yang telah dihitung adalah:

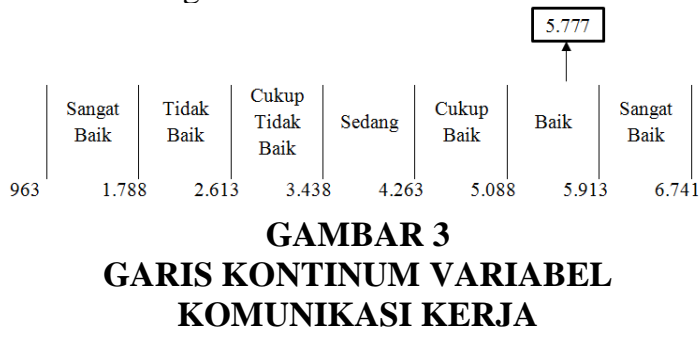

Berdasarkan Gambar 3 pada nilai kontinum variabel komunikasi kerja yaitu 5.777 sesuai dengan data penelitian yaitu termasuk kedalam kategori baik, dengan demikian dapat dikatakan bahwa komunikasi kerja perawat RS Paru Dr. H.A. Rotinsulu Bandung sudah baik.

Berdasarkan hasil penelitian dari angket yang disebar kepada 107 responden diketahui bahwa komunikasi kerja perawat RS Paru Dr. H.A. Rotinsulu Bandung mencapai skor 5.777 dari skor kriterium atau jumlah maksimal perolehan nilai responden terletak pada daerah 5.088 - 5.913, sehingga dapat dikatakan bahwa komunikasi kerja yang dimiliki oleh RS Paru Dr.
H.A. Rotinsulu Bandung telah diaplikasikan dengan baik, namun komunikasi kerja tersebut perlu ditingkatkan lagi, karena semua dimensi berada di bawah skor ideal. Komunikasi merupakan proses penyampaian atau penerimaan pesan dari satu orang kepada orang lain, baik langsung maupun tidak langsung, secara tertulis, secara lisan maupun bahasa non verbal (Usman, 2011: 420). Sementara menurut (Mulyana, 2014: 68) komunikasi merupakan transmisi informasi, gagasan, emosi, keterampilan, dan sebagainya dengan menggunakan simbol-simbol, kata-kata, gambar, figur, grafik, dan sebagainya. Tindakan atau proses transmisi itulah yang biasa disebut komunikasi.

Semangat kerja adalah kegiatan dalam melakukan pekerjaan secara lebih giat, sehingga dengan demikian pekerjaan akan diharapkan lebih cepat dan lebih baik (S.Nitisemito, 2014: 160). Menurut Sindang (2010: 57) semangat kerja adalah sejauh mana karyawan bergairah dalam melakukan tugas dan tanggung jawabnya di dalam perusahaan. Menurut S.Nitisemito (2014: 427) semangat kerja terbentuk atas 4 dimensi, naiknya produktivitas karyawan, tingkat absensi rendah, labour turnover, dan berkurangnya kegelisahaan

Karyawan yang semangat kerjanya tinggi cenderung melaksanakan tugas-tugas sesuai waktu, tidak menunda pekerjaan dengan sengaja, serta mempercepat pekerjaan dan sebagainya. oleh karena itu harus dibuat standar kerja untuk mengetahui apakah produktivitas karyawan yang tinggi apa tidak (S.Nitisemito, 2014: 427).

Tingkat absensi rendah merupakan salah satu indikasi meningkatnya semangat kerja, karena persentase absen seluruh karyawan rendah (S.Nitisemito, 2014: 427).

Menurut S.Nitisemito (2014: 427) karyawan yang menurun merupakan salah satu indikasi meningkatnya semangat kerja, hal ini dapat disebabkan oleh kesenangan mereka bekerja pada perusahaan tersebut. Tingkat keluar masuk karyawan yang tinggi dapat menggangu jalannya perusahaan.

Semangat kerja karyawan akan meningkat apabila mereka tidak gelisah. Kegelisahan dapat dilihat melalui bentuk keluhan, ketidaktenagaan bekerja, dan hal-hal lainnya (S.Nitisemito, 2014: 427).

Berdasarkan hasil pengolahan data yang dilakukan melalui penyebaran angket pada perawat RS Paru Dr. H.A. Rotinsulu Bandung, semangat kerja dapat diukur melalui perhitungan 
rata-rata dimensi dan perhitungan skor keseluruhan. Berikut ini dipaparkan hasil dari rekapitulasi perhitungan skor:

TABEL 3

REKAPITULASI DIMENSI SEMANGAT KERJA

\begin{tabular}{|c|c|c|c|c|}
\hline No & Dimensi & Skor Ideal & Total Skor & $\%$ \\
\hline 1 & Naiknya Produktifitas & 2.247 & 1.926 & 85,71 \\
\hline 2 & Tingkat Absensi Rendah & 2.996 & 2.527 & 84,34 \\
\hline 3 & Labor Turnover & 1.498 & 1.270 & 84,78 \\
\hline 4 & Berkurangnya Kegelisahan & 2.996 & 2.563 & 85,54 \\
\hline & TOTAL & 9.737 & 8.286 & 85,09 \\
\hline
\end{tabular}

Berdasarkan Tabel 3 rekapitulasi dimensi semangat kerja, skor tertinggi terdapat pada dimensi naikya produktifitas dengan peroleh skor 1.926 , termasuk dalam kategori naik $(85,71, \%)$. Keadaan lingkungan kerja yang kondusif akan memungkinkan pegawai mengerahkan diri untuk meningkatkan kinerjanya. Kenyamanan dari lingkungan kerja menentukan tingkat kepuasan dan produktivitas pegawai (Noah \& Steve, 2012) daya berharga seperti waktu, energi, dan emosi, yang penting untuk memenuhi kewajiban keluarga (Diane \& Tremblay, 2016).

Sementara skor terendah terdapat pada dimensi tingkat absensi rendah dengan skor 2.527, termasuk kedalam kategori rendah $(84,34 \%)$. Tingkat absensi rendah merupakan salah satu indikasi meningkatnya semangat kerja, karena persentase absen seluruh karyawan rendah (S.Nitisemito, 2014: 427)

Secara keseluruhan variabel semangat kerja memperoleh skor 8.286, apabila di persentasekan kedalam skor ideal maka diperoleh persentase sebesar 85,09\%, dengan demikian variabel semangat kerja berada pada kategori tinggi. Sedangkan dilihat dari garis kontinum yang telah dihitung adalah:

\section{GAMBAR 4 \\ GARIS KONTINUM VARIABEL SEMANGAT KERJA}

Berdasarkan Gambar 4 pada nilai kontinum variabel semangat kerja yaitu 8.286 sesuai dengan data penelitian yaitu termasuk kedalam kategori tinggi, dengan demikian dapat dikatakan bahwa semangat kerja perawat RS Paru Dr. H.A. Rotinsulu Bandung tinggi.

Berdasarkan hasil penelitian dari angket yang disebar kepada 107 responden diketahui bahwa semangat kerja perawat RS Paru Dr. H.A. Rotinsulu Bandung mencapai skor 8.286 dari skor kriterium atau jumlah maksimal perolehan nilai responden terletak pada daerah 7.351 - 8.543, sehingga dapat dikatakan bahwa semangat kerja yang dialami oleh perawat RS Paru Dr. H.A. Rotinsulu Bandung termasuk dalam kategori tinggi. Hal ini menunjukkan naiknya produktifitas pegawai, tingkat absensi rendah, labor turnover dan berkurangnya kegelisahan di RS Paru Dr. H.A. Rotinsulu Bandung dikatakan tinggi, akan tetapi semangat kerja harus ditingkatkan lagi karena semua dimensi masih dibawah skor ideal.

Berdasarkan penelitian diatas menyatakan bahwa semakin kondusif lingkungan kerja, maka semakin tinggi tingkat semangat kerja perawat RS Paru Dr. H.A. Rotinsulu Bandung. Selain itu, semakin baik komunikasi kerja perawat, maka semakin tinggi pula tingkat semangat kerja yang akan dialami oleh perawat RS Paru Dr. H.A. Rotinsulu Bandung.

\section{DAFTAR PUSTAKA}

A Devito, J. (2011). Komunikasi Antarmanusia. Tanggerang Selatan: Karisma Publishing Group.

Baker, E., \& McCabe, P. (2010). Inclusion of Communication Breakdown and Repair Sequences across Current Approaches to Phonological Intervention. Canadian Journal of Speech-Language Pathology and Audiology, 34(3).

Diane, S. M., \& Tremblay, G. (2016). Workload, generic and work - family specific social supports and job stress : mediating role of work-family and family-work conflict. International Journal of Contemporary Hospitality Management $\cdot$, 28(8).

Eko Sulistiyono, Patricia Dhiana Paramita, L. B. H. (2016). Pengaruh pendidikan, kemampuan kerja dan disiplin kerja terhadap semangat kerja karyawan harian lepas di pt temprina media grafika semarang. Journal of Management, 2(2).

Fauji, H. (2013). Terhadap Semangat Kerja Karyawan Di Pt . Karya Mandiri Environment Program Studi Manajemen, 18.

Fauzi, H. (2013). Pengaruh Stres Kerja dan Konflik Kerja terhadap Semangat Kerja Karyawan di PT. Karya Mandiri Environment.

Fry, L. W., Latham, J. R., Clinebell, S. K., \& Krahnke, K. (2016). Spiritual leadership as a model for performance excellence: a study of Baldrige award recipients Spiritual leadership as a model for performance excellence: a study of Baldrige award recipients. Journal of ManageMent, Spirituality \& Religion, 6086(July). https://doi.org/10.1080/14766086.2016.120 2130

Gouzali Saydam. (2008). Manajemen Sumber Daya Manusia (Jilid I). Jakarta: Gunung Agung.

M. Manullang. (2000). Manajemen Personalia. Jakarta: Ghalia Indonesia.

M, S. M. (2015). TERHADAP KINERJA KARYAWAN ( Studi Pada Karyawan PDAM Tirta Moedal Kota Semarang ). 
Mangkunegara, A. A. A. P. (2014). Manajemen Sumber Daya. Manusia Perusahaan. Bandung: Remaja Rosdakarya.

Marihot. (2009). Manajemen Sumber Daya Manusia. Jakarta: Grasindo.

Masharyono, \& Senen, S. H. (2015). Analisis Job Performance Pegawai Honorer Administrasi dengan Kompetensi dan Job Characteristics dalam Mendukung Universitas Pendidikan Indonesia Mencapai Leading and Outstanding. Jurnal Fokus Ekonomi, 10(2), 119-137.

McShane, S. L., \& Glinow, M. A. Von. (2018). Organizational behavior: emerging knowledge, global reality (Eight). New York: McGraw-Hill Education.

Mulyana, D. (2014). Ilmu Komunikasi: Suatu, 2014 (Cetakan ke). Bandung: PT. Remaja Rosdakarya.

Nitisemito, A. S. (1982). Manajemen Personalia. Jakarta: Ghalia Indonesia.

Noah, Y., \& Steve, M. (2012). Work Environment and Job Attitude among Employees in a Nigerian Work Organization. Journal of Sustainable Society, 1(2), 36-43.

Noviyanti, P., Suwena, K. R., \& Haris, I. A. (2015). Faktor-Faktor Yang Mempengaruhi Semangat Kerja Karyawan Pada Lembaga Perkreditan Desa (Lpd) Desa Sumberkima Di Kecamatan Gerokgak Tahun 2015. Jurnal Pendidikan Ekonomi, 5(1).

Nuryanti, B. L., \& Rahmawati, R. (2016). The Influence of Situational Leadership and Work Environment towards Employees ' Performance. Atlantis Press, 15, 540-543.

P Raja, R. S. K. (2015). Factors affecting employee morale and strategies adapted to build high employee morale. International Journal of Applied Research, 1(10), 264265.

Rewa, M. P., \& Tiwari, U. (2014). A STUDY ON EMPLOYEE MORALE AND ITS IMPACT ON EMPLOYEE EFFICIENCY AT JAYPEE CEMENT PLANT, 3(11).

Robbins, S. P., \& Judge, T. A. (2015). Organizational Behavior (16th ed.). New Jersey: Pearson.

Robbins, S. P., \& Judge, T. A. (2016). Organizational Behavior (17th ed.). United States: Pearson Education.

Sarode, A. P., \& Shirsath, M. (2016). The Factors Affecting Employee Work Environment \& It's Relation with Employee Productivity. International Journal of Science and Research (IJSR), 3(11).

Schermerhorn, J. R., Hunt, J. G., Osborn, R. N., \& Uhl-Bien, M. (2010). Organizational Behavior, 678.
Secchi, D., \& Neumann, M. (2016). Agent-Based Simulation of Organizational Behavior. https://doi.org/10.1007/978-3-319-181530_16

Sedamaryanti. (2011). Manajemen Sumber Daya Manusia, Reformasi Birokrasi dan Manajemen Pegawai Negeri Sipil. Bandung: PT Rafika Aditama.

Sedarmayanti. (2011). Manajemen Sumber Daya Manusia, Reformasi Birokrasi dan Manajemen Pegawai Negeri Sipil (Kelima). Bandung: PT Rafika Aditama.

Senen, S. H., Sumiyati, \& Masharyono. (2016). The Effect of Skill Variety, Task Identity, Task Significance, Autonomy and Feedback on Job Performance. Economics, Business and Management, 15, 585-588. https://doi.org/10.2991/gcbme-16.2016.108

Senen, S. H., \& Triananda, N. (2016a). The Employee Performance Influenced by Communication: a Study of BUMD in Indonesia. Atlantis Press, 15, 596-598.

Senen, S. H., \& Triananda, N. (2016b). The Employee Performance Influenced by Communication: a Study of BUMD in Indonesia, 15, 596-598.

Siagian, S. P. (2003). Manajemen Sumber Daya Manusia. Jakarta: Bumi Aksara.

Sindang, S. (2010). Manajemen Sumber Daya Manusia (Cetakan Ke). Jakarta: PT. Bumi Aksara.

Sunyoto, D. (2012). Manajemen Sumber Daya Manusia. Yogyakarta: CAPS.

Tabachnick, \& Fidell. (2013). Using Multivariate Statisrics, Sixth Edition. Boston: Pearson Education, Inc.

Upadhyay, D. (2012). ISSN : 2249-5894 Gaining Competitive Edge ISSN : 2249-5894, 2(7), 80-94.

Upadhyay, D., \& Gupta, A. E. (2012). Morale, Welfare measures, Job Satisfaction: The Key Mantras for Gaining Competitive Edge. International Journal of Physical and Social Sciences, 91.

Usman, H. (2011). Manajemen: Teori, Praktik, dan Riset Pendidikan. Jakarta: Bumi Aksara.

Wantania1, Y. I., \& Lapian2, S. L. H. V. J. (2015). THE EFFECT OF EMPLOYEE MORALE AND FACILITIES TOWARD EMPLOYEE EFFICIENCY OF PT ASTRA INTERNATIONAL TBK DAIHATSU MANADO, 3(3), 411-419.

Wibowo, M., Musadieq, M. Al, \& Nurtjahjono, G. E. (2014). Pengaruh Lingkungan Kerja Terhadap Kepuasan Kerja Karyawan. Jurnal Administrasi Bisnis (JAB), 16(1), 19.

Widyanata, R., \& Senen, S. H. (2016). Pengaruh 
Journal of Business Management Education | Volume 3, Number 3, December 2018, page. 34-44

Lingkungan Dan Kemampuan Kerja

Terhadap Kinerja Karyawan PT. Ronadamar Sejahtera Cabang Bandung. Journal of Business Management Education, 1(2), 47-55.

Wilkinson, A., Redman, T., \& Dundon, T. (2017). Contemporary Human Resource Management. United Kingdom: Pearson.

Zainun, B. (2013). Manajemen dan Komunikasi. Jakarta: Balai Pustaka.

Zia, S. (2016). Conceptual Frame Works on Employee Morale and Satisfaction in Work Place, (1), 312-318. 